\title{
Influence of Different Levels of Drip Fertigation and Mulching on Growth, Yield, Water Productivity and Nutrient Uptake of Pigeonpea (Cajanus cajan L.)
}

Sunil Kumar, C. Seenappa, Vikramarjun Madam, M.R. Anand

10.18805/LR-4691

\begin{abstract}
Background: Pigeonpea is second most important pulse crop grown after chickpea in India. Pigeonpea is versatile crop can be grown in vast agro climatic condition with low inputs. However, the yield is very low as compared to the potential yield as grown in rainfed condition, the drip fertigation and mulching can increase resource use efficiency. Both these techniques are resource saving and realized maximum yield by reducing the nutrient and water losses as compared to conventional practices.

Methods: The experiment was laid out in factorial complete randomized block design and replicated thrice. The experiment consisted of two levels of irrigation ( $0.50 \mathrm{CPE}$ and $0.75 \mathrm{CPE}$ ) as one factor and three fertility levels (100\% RDF, $75 \% \mathrm{RDF}$ and $50 \% \mathrm{RDF}$ ) as second factor and two levels of mulching (without mulching and with plastic mulching 25 micron) as third factor.

Result: The results revealed that higher level of irrigation (0.75 CPE) with 100 per cent RDF and with plastic mulching recorded significantly higher growth rate, seed yield and uptake of nutrients by the pigeonpea crop.
\end{abstract}

Key words: Drip irrigation, Fertigation, Mulching, Pigeonpea, Water productivity

\section{INTRODUCTION}

Pigeonpea [Cajanus cajan (L.) Millsp.] also known as red gram, Tur or arhar is the fifth major pulse crop grown throughout the globe and second prominent pulse crop in India after chickpea. Global pigeonpea cultivation increased at an annual rate of $1.3 \%$ from about 2.7 million hectares in 1961 to about 4.6 million hectares in 2007 and production grew at an annual rate of $2.5 \%$ from about 2.2 million tons in 1961 to about 3.4 million tons in 2007 representing an increase of about $54 \%$ (FAO, 2008). Pigeonpea remained at second position in total pulse production with $4.25 \mathrm{~m} \mathrm{t}$ recorded in an area of $4.45 \mathrm{~m}$ ha with average productivity of $960 \mathrm{~kg} \mathrm{ha}^{-1}$ (Anonymous, 2018) in the country. Pigeonpea has good yield potential but production and productivity is very low because it is cultivated as rainfed crop in marginal lands of semi-arid tropics.

Drip irrigation has significant impact on resource saving, crop yield and profitability of farm compared to other means of irrigation methods. Drip fertigation is a highly input efficient method to minimize the irrigation losses, better fertilizer application and adverse environmental impact on crop production. Both water and nutrient uptake enhanced by the plants and realized maximum dry matter production and yield through drip fertigation (Ramana Rao et al., 2018). The nutrient and water losses from the soil is minimized through mulching and they are utilized effectively to a greater extent. Among the production factors of crop production, irrigation and nutrient management has immense importance in profitable farming. Mulching is one of the most promising practice among different methods of moisture conservation. Mulching helps to reduce the evaporation
Department of Agronomy, Gandhi Krishi Vigyan Kendra, University of Agricultural Sciences, Bangalore-560 065, Karnataka, India.

Corresponding Author: Sunil Kumar, Department of Agronomy, Gandhi Krishi Vigyan Kendra, University of Agricultural Sciences, Bangalore-560 065, Karnataka, India.

Email: sunilbhardwaj8207@gmail.com

How to cite this article: Kumar, S., Seenappa, C., Madam, V. and Anand, M.R. (2021). Influence of Different Levels of Drip Fertigation and Mulching on Growth, Yield, Water Productivity and Nutrient Uptake of Pigeonpea (Cajanus cajan L.). Legume Research. DOI: 10.18805/LR-4691.

Submitted: 09-06-2021 Accepted: 30-10-2021 Online: 17-01-2022

losses from soil, preventing the soil particles from direct contact of rain drops which helps to control the soil erosion and check run-off losses. Application of mulching on soil surface helps to maintain the optimum soil temperature which favours plant growth, suppress the weed growth and prevent the nutrient losses from the soil (Kamar et al., 2018). Thus to combat with the moisture stress under rainfed condition, an experiment was conducted with objectives to find out the effect of drip fertigation under different nutrient levels and mulching.

\section{MATERIALS AND METHODS}

A field experiment was conducted during Kharif 2019 at Zonal Agricultural Research Station (ZARS), Gandhi Krishi Vigyan Kendra (GKVK), University of Agricultural Sciences (UAS), Bangalore. The center is situated in the agro-climatic zone V: Eastern Dry Zone of Karnataka at $12^{\circ} 58^{\prime}$ North 
latitude and $77^{\circ} 35^{\prime}$ East longitude with an altitude of $930 \mathrm{~m}$ above mean sea level, the soil of experimental site was red sandy loam. The experiment consisted of two levels of irrigation (0.50 CPE and $0.75 \mathrm{CPE}$ ) as one factor and three fertility levels (100\% RDF, 75\% RDF and 50\% RDF) as second factor and two levels of mulching (without mulching and with plastic mulching 25 micron) as third factor. The soil was low in available nitrogen (262.08 $\left.\mathrm{kg} \mathrm{ha}^{-1}\right)$, medium in available phosphorus (20 kg ha-1) and available potassium (269.7 $\left.\mathrm{kg} \mathrm{ha}^{-1}\right)$. The soil was acidic in nature (5.87) with electrical conductivity in the safer range. The RDF (recommended dose of fertilizer) 25:50:25 N, $\mathrm{P}_{2} \mathrm{O}_{5}$ and $\mathrm{K}_{2} \mathrm{O}$ $\mathrm{kg} \mathrm{ha}^{-1}$ was respectively, which was applied through urea DAP and MOP. Cultivar BRG-5 was sown in paired row with spacing of 180 between two paired, $60 \mathrm{~cm}$ within pair and $30 \mathrm{~cm}$ plant to plant $(180 / 60 \mathrm{~cm} \times 30 \mathrm{~cm})$. Drip irrigation was schedule once in week up to flowering and then once in every three days after flowering based on CPE value.

\section{RESULTS AND DISCUSSION}

\section{Influence of drip fertigation and mulching on growth parameters of pigeonpea}

Growth parameters of pigeonpea were affected significantly due to various levels of irrigation, fertility levels and mulching were presented (Table 1 and 1.1).

\section{Plant height}

The increase in plant height up to 40 DAS is very slow because of initial slow growth rate of pigeonpea, thereafter plant height increased linearly at 80 and 120 DAS as this is the grand growth period. Thereafter, growth occurred at diminishing rate with different factors like irrigation, fertigation and mulching. The increase in plant height was due to optimum availability of moisture at $0.75 \mathrm{CPE}$ in entire growth period and there was no competition from weeds because weeds were suppressed by mulching and efficient utilization of fertilizers applied through drip irrigation. The findings are similar with the findings of Mathukia et al. (2015) and Ramana Rao et al. (2018).

\section{Leaf area $\left(\mathrm{cm}^{2}\right.$ plant $\left.{ }^{-1}\right)$}

The highest leaf area plant ${ }^{-1}$ was recorded with $0.75 \mathrm{CPE}$, 100 per cent RDF and mulching may be due to controlled environmental condition and more interception of sunlight and more photosynthesis might have increased leaf area plant $^{-1}$. This may be because of optimum moisture and nutrient availability synchronizing with supply and demand of nutrients and by conserving the more moisture and controlling the weed growth by the mulching. The interaction effects of all the factors were higher because of more availability of nutrients, moisture and uptake of nutrients was also higher. Ramana Rao et al. (2018), Shirgapure and Fathima (2018) and Solanki et al. (2019) have also recorded same trends in leaf area plant ${ }^{-1}$.

\section{Dry matter accumulation}

The dry matter accumulation during initial crop growth period was very less because of initial slow growth and it progressively increased up to 120 DAS thereafter increase with diminishing rate up to harvest because dry matter is a function of leaf area, number of branches and more number of leaves which was maximum at 120 DAS and then decline due to leaf senescence. At harvest, higher dry weight plant ${ }^{-1}$ was observed with irrigation at $0.75 \mathrm{CPE}(121.8 \mathrm{~g})$ while lower dry matter accumulation plant ${ }^{-1}$ with irrigation at 0.50 CPE $(111.8 \mathrm{~g})$. The total dry matter accumulation plant ${ }^{-1}$ was noticed in higher levels of fertigation i.e., 100 per cent RDF $(122.7 \mathrm{~g})$ followed by 75 per cent RDF (114.3 g) and 50 per cent RDF $(113.3 \mathrm{~g})$, respectively. The dry matter plant ${ }^{-1}$ with mulching $(124.0 \mathrm{~g})$ was significantly higher than without mulching $(109.5 \mathrm{~g})$. The increase in dry matter of pigeonpea up to harvest is due to sufficient availability of moisture and reduce the weed growth and low evaporation loss of moisture from the soil due to mulching effect. Higher fertigation levels provide more nutrients to plant which helped in vigorous growth of the plant contributed to more dry matter production. These findings were similar with Shirgapure and Fathima (2018) and Swathi et al. (2018).

\section{Influence of drip fertigation and mulching on yield parameters and yield of pigeonpea}

yield parameters and yield as influenced with different levels of irrigation and mulching are presented in Table 2 and 2.1.

\section{Number of pods plant ${ }^{-1}$}

Maximum pods plant $^{-1}$ was recorded under higher levels of irrigation at 0.75 CPE (172.5) which significantly differed from irrigation at $0.50 \mathrm{CPE}$ (149.8). The higher number of pods plant $^{-1}$ was noticed in 100 per cent RDF (172.6) and lower in 50 per cent RDF (148.5). Among the mulching treatments maximum number of pods plant ${ }^{-1}$ was recorded with plastic mulching $M_{1}$ (178.4) compared to without mulching (143.9). The possible reason for higher number of pods plant ${ }^{-1}$ due to sufficient moisture, more availability of nutrients and absorption of nutrients, luxurious vegetative growth and lower flower dropping. These results were in accordance with, Savani et al. (2017) and Shirgapure and Fathima (2018).

\section{Number of seeds pod $^{-1}$}

Number of seeds pod $^{-1}$ were influenced significantly with irrigation, fertility and mulching levels. Irrigation with 0.75 CPE recorded significantly higher number of seeds pod $^{-1}$ (4.5) than 0.50 CPE (4.1). The higher levels of fertilizer with 100 per cent RDF (4.6) fortified significantly higher number of seeds than rest of fertigation levels. Mulching treatment recorded higher number of seeds pod $^{-1}$ (4.5) than no mulching (4.1). The higher number of seeds pod $^{-1}$ were recorded with higher moisture regime and mulching. This was probably due to more vegetative growth, more flowering and efficient partition between source and sink. The similar results were also reported by Ramana Rao et al. (2018).

\section{Seed yield}

The crop irrigated with drip system at 0.75 CPE recorded 


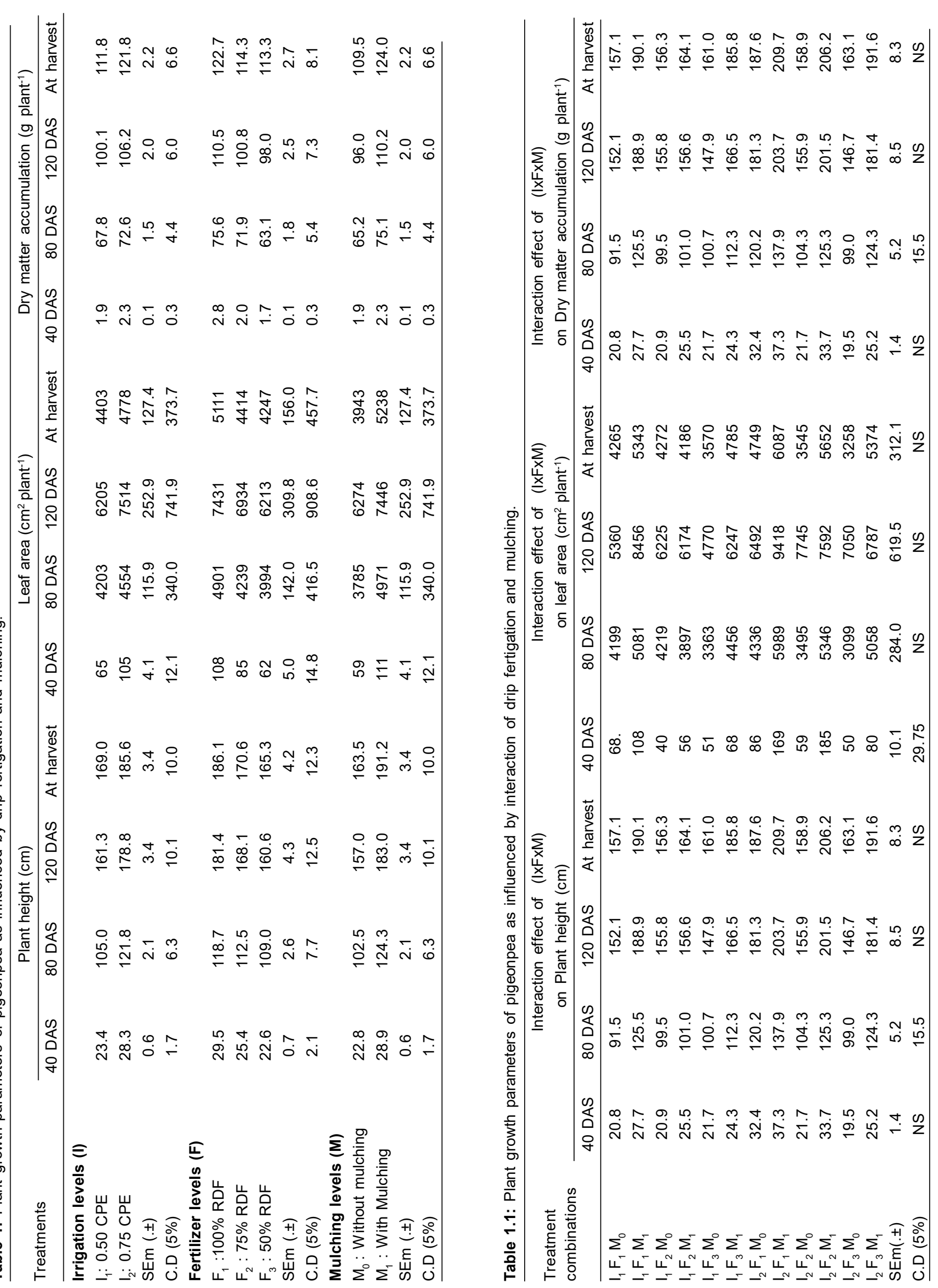


Influence of Different Levels of Drip Fertigation and Mulching on Growth, Yield, Water Productivity and Nutrient Uptake...

higher seed yield (1364 $\left.\mathrm{kg} \mathrm{ha}^{-1}\right)$ compared to lower irrigation at $0.50 \mathrm{CPE}\left(1166 \mathrm{~kg} \mathrm{ha}^{-1}\right)$. The highest seed yield was obtained with higher levels of fertigation with 100 per cent RDF (1509 kg ha-1) followed by 75 and 50 per cent RDF (1197 and $1089 \mathrm{~kg} \mathrm{ha}^{-1}$, respectively). Significantly higher seed yield was recorded with plastic mulching (1423 $\left.\mathrm{kg} \mathrm{ha}^{-1}\right)$ as compared to without mulching $\left(1107 \mathrm{~kg} \mathrm{ha}^{-1}\right)$. Seed yield of pigeonpea was significantly higher due to individual factors and their interaction effects. This was because of higher levels of irrigation provide optimum moisture to plant and higher fertility levels provides more nutrients to plant in available form and reduce the losses of nutrients because they were supplied through drip irrigation which helps to match the supply and demand of crops. Mulching reduces the evaporation losses of moisture from the soil and maintains optimum temperature and also reduces the weeds which helps to provide weed free condition as such the crop growth was good and contributes higher seed yield. Similar findings were reported by Savani et al. (2017) and Kamar et al. (2018).

The interaction effect of drip fertigation and mulching on yield and water productivity of pigeonpea (Table 2). Revealed that treatment combination $\mathrm{I}_{2} \mathrm{~F}_{1} \mathrm{M}_{1}$ (0.75 CPE, $100 \%$ RDF and with plastic mulching) recorded significantly higher yield $\left(2091 \mathrm{~kg} \mathrm{ha}^{-1}\right)$ compared to rest of treatment combinations.

\section{Stalk yield}

The stalk yield of pigeonpea was influenced significantly due to different levels of irrigation, fertigation and mulching. The crop irrigated with drip at $0.75 \mathrm{CPE}$ recorded higher stalk yield (3777 $\left.\mathrm{kg} \mathrm{ha}^{-1}\right)$ compared to the lower level of irrigation with 0.50 CPE (3464 $\left.\mathrm{kg} \mathrm{ha}^{-1}\right)$. The highest stalk yield ha-1 was obtained with 100 per cent RDF (3815 kg ha-1) followed by 75 per cent and 50 per cent RDF (3620 and $3426 \mathrm{~kg} \mathrm{ha}^{-1}$, respectively). Higher stalk yield ha-1 was recorded with mulching (3923 $\mathrm{kg} \mathrm{ha}^{-1}$ ) as compared to without mulching $\left(3318 \mathrm{~kg} \mathrm{ha}^{-1}\right)$. Similar results have been found by Patel et al. (2015) and Mathukia et al. (2015). This might be due to optimum moisture available during entire crop growth period and fertilizers were applied through drip which reduce losses and efficiently uptake of nutrients led to taller plant, maximum number of branches and more leaf area plant ${ }^{-1}$ and finally more dry matter or stalk yield. Further mulching reduces the competition for nutrients and space by suppressing the weeds which helps to increase plant canopy vigorously and produce more stalk yield.

\section{Effect of drip fertigation and mulching on water productivity of pigeonpea}

The water productivity of different irrigation levels (0.50 CPE) and $\left(0.75\right.$ CPE) was obtained 67.3 and $59.4 \mathrm{~kg} \mathrm{ha-cm}^{-1}$ respectively which indicates that water productivity at 0.50 CPE was significantly higher than $0.75 \mathrm{CPE}$ (Table 2 and 2.1). Higher water productivity was recorded in higher fertigation level of 100 per cent RDF (75.3 kg ha-cm-1) followed by 75 per cent RDF and 50 per cent RDF (59.8

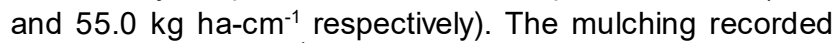

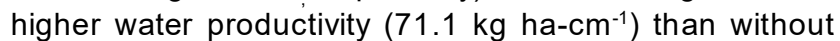
mulching $\left(55.7 \mathrm{~kg}\right.$ ha- $\left.\mathrm{cm}^{-1}\right)$. The similar findings were reported by Kumar et al. (2016) and Savani et al. (2017).

The interaction effect of irrigation, fertigation and mulching on water productivity was found to be significant.

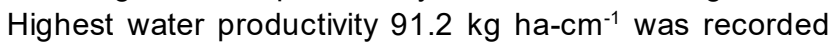
with $\mathrm{I}_{2} \mathrm{~F}_{1} \mathrm{M}_{1}(0.75 \mathrm{CPE}, 100 \% \mathrm{RDF}$ and with mulching) than rest of the treatment combinations, but on par with $\mathrm{I}_{1} \mathrm{~F}_{1} \mathrm{M}_{1}$ i.e. (0.50 CPE, $100 \%$ RDF and with mulching) $84.1 \mathrm{~kg}$ ha$\mathrm{cm}^{-1}$. Similar finding was reported by Solanki et al. (2019).

These results indicated that lower levels of irrigation recorded higher water productivity because of more yield was produced with less amount of water. Higher water productivity was observed with interaction effect because

Table 2: yield attributes, yield and water productivity of pigeonpea as influenced by drip fertigation and mulching.

\begin{tabular}{|c|c|c|c|c|c|}
\hline Treatments & Pods per plant & $\begin{array}{c}\text { Number of seeds } \\
\text { per pods }\end{array}$ & $\begin{array}{l}\text { Seed yield } \\
\left(\mathrm{kg} \mathrm{ha}^{-1}\right)\end{array}$ & $\begin{array}{l}\text { Stalk yield } \\
\left(\mathrm{kg} \mathrm{ha}^{-1}\right)\end{array}$ & 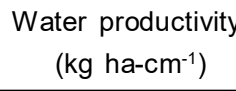 \\
\hline \multicolumn{6}{|l|}{ Irrigation levels (I) } \\
\hline $\mathrm{I}_{1}: 0.50 \mathrm{CPE}$ & 149.8 & 4.1 & 1166 & 3464 & 67.3 \\
\hline $\mathrm{I}_{2}: 0.75 \mathrm{CPE}$ & 172.5 & 4.5 & 1364 & 3777 & 59.4 \\
\hline 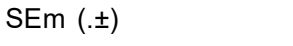 & 4.5 & 0.1 & 29.5 & 75.8 & 1.5 \\
\hline C.D (5\%) & 13.4 & 0.3 & 86.5 & 222.3 & 4.4 \\
\hline \multicolumn{6}{|l|}{ Fertilizer levels (F) } \\
\hline $\mathrm{F}_{1}: 100 \% \mathrm{RDF}$ & 172.6 & 4.6 & 1509 & 3815 & 75.3 \\
\hline $\mathrm{F}_{2}: 75 \% \mathrm{RDF}$ & 162.4 & 4.3 & 1197 & 3620 & 59.8 \\
\hline $\mathrm{F}_{3}: 50 \% \mathrm{RDF}$ & 148.5 & 4.0 & 1089 & 3426 & 55.0 \\
\hline $\operatorname{SEm}(. \pm)$ & 5.6 & 0.1 & 36.1 & 92.8 & 1.8 \\
\hline C.D $(5 \%)$ & 16.5 & 0.4 & 106.0 & 272.3 & 5.45 \\
\hline \multicolumn{6}{|l|}{ Mulching levels (M) } \\
\hline $\mathrm{M}_{0}$ : Without mulching & 143.9 & 4.1 & 1107 & 3318 & 55.7 \\
\hline $\mathrm{M}_{1}:$ With Mulching & 178.4 & 4.5 & 1423 & 3923 & 71.1 \\
\hline $\operatorname{SEm}(. \pm)$ & 4.5 & 0.1 & 29.5 & 75.8 & 1.5 \\
\hline C.D (5\%) & 13.4 & 0.3 & 86.5 & 222.3 & 4.4 \\
\hline
\end{tabular}


Influence of Different Levels of Drip Fertigation and Mulching on Growth, Yield, Water Productivity and Nutrient Uptake...

Table 2.1: Yeld attributes, yield and water productivity of pigeonpea as influenced by interaction of drip fertigation and mulching.

\begin{tabular}{|c|c|c|c|c|c|}
\hline $\begin{array}{l}\text { Treatment } \\
\text { combinations }\end{array}$ & Pods per plant & $\begin{array}{c}\text { Number of seeds } \\
\text { per plant }\end{array}$ & $\begin{array}{l}\text { Seed yield } \\
\left(\mathrm{kg} \mathrm{ha}^{-1}\right)\end{array}$ & $\begin{array}{l}\text { Stalk yield } \\
\left(\mathrm{kg} \mathrm{ha}^{-1}\right)\end{array}$ & 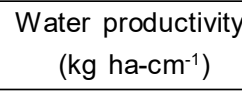 \\
\hline $\mathrm{I}_{1} \mathrm{~F}_{1} \mathrm{M}_{0}$ & 139.5 & 4.3 & 1238 & 3204 & 71.5 \\
\hline $\mathrm{I}_{1} \mathrm{~F}_{1} \mathrm{M}_{1}$ & 178.5 & 4.6 & 1457 & 4133 & 84.1 \\
\hline $\mathrm{I}_{1} \mathrm{~F}_{2} \mathrm{M}_{0}$ & 138.3 & 4.1 & 936 & 3129 & 54.1 \\
\hline $\mathrm{I}_{1} \mathrm{~F}_{2} \mathrm{M}_{1}$ & 168.8 & 4.2 & 1227 & 3726 & 70.9 \\
\hline $\mathrm{I}_{1} \mathrm{~F}_{3} \mathrm{M}_{0}$ & 128.9 & 3.6 & 985 & 3116 & 56.9 \\
\hline $\mathrm{I}_{1} \mathrm{~F}_{3} \mathrm{M}_{1}$ & 145.4 & 4.1 & 1152 & 3476 & 66.5 \\
\hline $\mathrm{I}_{2} \mathrm{~F}_{1} \mathrm{M}_{0}$ & 151.4 & 4.6 & 1249 & 3602 & 54.5 \\
\hline $\mathrm{I}_{2} \mathrm{~F}_{1} \mathrm{M}_{1}$ & 221.3 & 5.1 & 2091 & 4323 & 91.2 \\
\hline $\mathrm{I}_{2} \mathrm{~F}_{2} \mathrm{M}_{0}$ & 153.5 & 4.4 & 1219 & 3526 & 53.1 \\
\hline $\mathrm{I}_{2} \mathrm{~F}_{2} \mathrm{M}_{1}$ & 189.4 & 4.7 & 1407 & 4098 & 61.4 \\
\hline $\mathrm{I}_{2} \mathrm{~F}_{3} \mathrm{M}_{0}$ & 152.4 & 4.0 & 1013 & 3332 & 44.2 \\
\hline $\mathrm{I}_{2} \mathrm{~F}_{3} \mathrm{M}_{1}$ & 167.4 & 4.3 & 1206 & 3781 & 52.6 \\
\hline $\operatorname{SEm}(. \pm)$ & 11.2 & 0.2 & 72.2 & 185.7 & 3.7 \\
\hline C.D (5\%) & NS & NS & 212.0 & NS & 10.9 \\
\hline
\end{tabular}

Table 3: Nutrient uptake by pigeonpea as influenced by drip fertigation and mulching.

\begin{tabular}{|c|c|c|c|}
\hline Treatments & $\begin{array}{c}\mathrm{N} \\
\left(\mathrm{kg} \mathrm{ha}^{-1}\right)\end{array}$ & $\begin{array}{c}\mathrm{P}_{2} \mathrm{O}_{5} \\
\left(\mathrm{~kg} \mathrm{ha}^{-1}\right)\end{array}$ & $\begin{array}{c}\mathrm{K}_{2} \mathrm{O} \\
\left(\mathrm{kg} \mathrm{ha}^{-1}\right)\end{array}$ \\
\hline \multicolumn{4}{|l|}{ Irrigation levels (I) } \\
\hline $\mathrm{I}_{1}: 0.50 \mathrm{CPE}$ & 60.4 & 8.9 & 86.8 \\
\hline $\mathrm{I}_{2}: 0.75 \mathrm{CPE}$ & 64.6 & 9.5 & 92.5 \\
\hline $\operatorname{SEm}(. \pm)$ & 1.2 & 0.1 & 1.7 \\
\hline C.D $(5 \%)$ & 3.7 & 0.5 & 5.1 \\
\hline \multicolumn{4}{|l|}{ Fertilizer levels (F) } \\
\hline $\mathrm{F}_{1}: 100 \% \mathrm{RDF}$ & 67.7 & 10.2 & 96.5 \\
\hline $\mathrm{F}_{2}: 75 \% \mathrm{RDF}$ & 62.7 & 9.1 & 89.9 \\
\hline $\mathrm{F}_{3}: 50 \% \mathrm{RDF}$ & 57.1 & 8.3 & 82.5 \\
\hline SEm (.土) & 1.5 & 0.2 & 2.1 \\
\hline C.D $(5 \%)$ & 4.6 & 0.6 & 6.2 \\
\hline \multicolumn{4}{|l|}{ Mulching levels (M) } \\
\hline $\mathrm{M}_{0}$ : Without mulching & 60.5 & 8.7 & 86.9 \\
\hline$M_{1}:$ With Mulching & 64.5 & 9.7 & 92.4 \\
\hline $\operatorname{SEm}(. \pm)$ & 1.2 & 0.1 & 1.7 \\
\hline C.D $(5 \%)$ & 3.7 & 0.5 & 5.1 \\
\hline \multicolumn{4}{|c|}{ Treatment combinations } \\
\hline $\mathrm{I}_{1} \mathrm{~F}_{1} \mathrm{M}_{0}$ & 61.5 & 9.5 & 87.9 \\
\hline$I_{1} F_{1} M_{1}$ & 66.4 & 10.3 & 98.7 \\
\hline$I_{1} F_{2} M_{0}$ & 59.0 & 8.2 & 83.3 \\
\hline $\mathrm{I}_{1} \mathrm{~F}_{2} \mathrm{M}_{1}$ & 62.5 & 9.3 & 91.7 \\
\hline$I_{1} F_{3} M_{0}$ & 55.8 & 7.8 & 78.9 \\
\hline $\mathrm{I}_{1} \mathrm{~F}_{3} \mathrm{M}_{1}$ & 57.4 & 8.6 & 80.4 \\
\hline $\mathrm{I}_{2} \mathrm{~F}_{1} \mathrm{M}_{0}$ & 68.8 & 9.6 & 96.7 \\
\hline $\mathrm{I}_{2} \mathrm{~F}_{1} \mathrm{M}_{1}$ & 74.3 & 11.6 & 102.8 \\
\hline $\mathrm{I}_{2} \mathrm{~F}_{2} \mathrm{M}_{0}$ & 62.5 & 9.4 & 91.5 \\
\hline $\mathrm{I}_{2} \mathrm{~F}_{2} \mathrm{M}_{1}$ & 66.7 & 9.8 & 93.3 \\
\hline $\mathrm{I}_{2} \mathrm{~F}_{3} \mathrm{M}_{0}$ & 55.9 & 8.2 & 83.3 \\
\hline $\mathrm{I}_{2} \mathrm{~F}_{3} \mathrm{M}_{1}$ & 59.6 & 8.8 & 87.7 \\
\hline SEm (.. & 3.1 & 0.4 & 4.2 \\
\hline C.D (5\%) & NS & NS & NS \\
\hline
\end{tabular}

of more yield was obtained and less evaporation losses from soil surface (Solanki et al., 2019). Savani et al. (2017) reported that the water use efficiency obtained under irrigation levels of $0.4,0.6$ and $0.8 \mathrm{CPE}$ through drip and surface irrigation were $3.65,3.02,2.45$ and $1.90 \mathrm{~kg} \mathrm{ha}^{-\mathrm{mm}^{-1}}$ of water used, respectively. This indicated that WUE decreased with increase in level of irrigation. Drip irrigation scheduled at lower level (0.4 CPE) recorded higher WUE

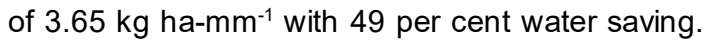

Effect of drip fertigation and mulching on nutrients uptake of pigeonpea

The data concerning to nutrient uptake of major nutrients by pigeonpea at harvest as influenced by drip fertigation and mulching and their interactions are presented in Table 3 and 3.1. The uptake of the nutrients by pigeonpea have shown significant effect at the time of harvest. Higher irrigation level 0.75 CPE recorded significantly higher uptake of nitrogen, phosphorous and potassium by crop (64.6, 9.5 and $92.5 \mathrm{~kg} \mathrm{ha}^{-1}$, respectively) and it was followed by lower level of irrigation 0.50 CPE $\left(60.4,8.9\right.$ and $86.8 \mathrm{~kg} \mathrm{ha}^{-1}$, respectively). Among different levels of fertigation, the higher uptake of nitrogen, phosphorous and potassium was recorded with 100 per cent $\operatorname{RDF}\left(67.7,10.2\right.$ and $96.5 \mathrm{~kg} \mathrm{ha}^{-1}$, respectively) compared to lower levels of fertigation. Higher uptake of nitrogen, phosphorous and potassium by pigeonpea was observed with mulching (64.5, 9.7 and 92.4 $\mathrm{kg} \mathrm{ha}^{-1}$, respectively) compared to without mulching (60.5, 8.7 and $86.9 \mathrm{~kg} \mathrm{ha}^{-1}$, respectively). This was due to ready availability of major nutrients in available form near crop root zone because of optimum moisture at higher level of irrigation and crop microclimate was maintained by mulching with higher level of fertility. The interaction effect of different factors recorded non-significant results of nutrients uptake. The similar findings were recorded by Shankarlingappa et al. (2000) and Chaudhary et al. (2010). 


\section{CONCLUSION}

The increasing human population day by days needs higher pulse production for satisfying the nutritive protein requirements. We are celebrating international pulse years 2016 and we will produce more amounts of pulses in upcoming centuries. Based on the above investigation it can be concluded that application of treatment combination $\left(\mathrm{I}_{2}\right.$ $\mathrm{F}_{1} \mathrm{M}_{1}$ ) $0.75 \mathrm{CPE}+100$ per cent RDF gives higher plant growth, yield attributes, yield and productivity with saving of natural resources and enhance the use efficiencies.

\section{REFERENCES}

Anonymous. (2018). Annual Report Directorate of Pulse Development, Ministry of Agriculture and Family Welfare, Government of India. pp. 38-39.

Chaudhari, P.R., Wani, P.V., Bachkar, C.B and Bhalerao, V.K. (2010). Response of pigeonpea to phosphate solubilizing biofertilizers. Journal of Maharashtra Agricultural Universities 35(2): 238-40.

FAOSTAT, (2008). Online agricultural statistics. www.faostat.org

Kamar, S.S.A., Khan, M.H. and Uddin, M.S. (2018). Effect of irrigation and mulch on maize yield (Zea mays) in southern areas of Bangladesh. J. Agri. Crop Res. 6(2): 28-37.

Kumar, R., Pal, R., Kumar, R., Sagar, S. and Ankur, S.B. (2016). Response of water use efficiency through fertigation on growth and yield of chilli crop. Inter. J. Engi. Sci. and Res. Tech. 5(12):

Mathukia, R.K., Mathukia, P.R. and Polara, A.M. (2015). Effect of preparatory tillage and mulch on productivity of rainfed pigeonpea [Cajanus cajan (L.) Millsp.]. Ind. J. Dryland Agric. Res. and Dev. 30(2): 58-61.
Patel, A.R., Gohel, T.J., Davara, D.K. and Solanki, M.H. (2015). Effect of drip irrigation and mulching on growth, yield and water use efficiency of rabi pigeonpea (Cajanus cajan L.). Trends in Biosciences. 8(16): 4275-4279.

Ramana, Rao, K.V., Aherwar Pushplata, Gangwar, S., Kumar, S. and Yadav, D. (2018). Growth, yield, economics, water use efficiency and microbial functions of pigeonpea crop influenced by drip irrigation with plastic mulch. Inter. J. Curr. Microbiol. App. Sci. 7(12): 2284-2290.

Shankaralingappa, B.C., Shivraj, B., Sudhir, K and Vishwanatha, K.P. (2000). Interaction effect of phosphorus and sulphur on uptake of nitrogen, phosphorus, potassium and sulphur by Pigeonpea. Indian Journal of Agronomy. 45: 348-352.

Shirgapure, K.H. and Fathima, P.S. (2018). Growth and yield of pulses as influenced by irrigation levels in southern dry zone of Kanataka. J. Pharmacognosy and Phytochem. 7(1): 2444-2448.

Solanki, M.A., Chalodia, A.L., Fadadu, M.H. and Dabhi, P.V. (2019). Response of pigeonpea to drip irrigation and mulching. Inter. J. Curr. Microbiol. App. Sci. 8(2): 91-97.

Savani N.G., Patel R.B. Solia B.M., Patel J.M. and Usadadiya V.P. (2017). Productivity and profitability of rabi pigeonpea increased through drip irrigation with mulch under south Gujarat condition. Inter. J. Agri. Innov. Res. 5(5): 23191473.

Swathi, Y.M., Srinivasa Reddy, Prabhakara, G.R. and Kavitha, P. (2018). Efficacy of polythene mulch technology in improving growth, flowering behavior and yield of irrigated pigeonpea in Andhra Pradesh. Inter. J. Curr. Microbiol. and App. Sci. 6: 1769-1773. 